J. Asiat. Soc. Bangladesh, Sci. 39(1): 21-26, June 2013

\title{
EFFECT OF HERBICIDES ON THE GROWTH, YIELD COMPONENTS AND YIELD OF BR11 PADDY
}

\author{
A.B. ZIAUDDIN HOSSAIN AND MD. AZIZUR RAHMAN \\ Department of Botany, University of Chittagong, Chittagong, Bangladesh
}

\begin{abstract}
Eleven treatments with three herbicides were applied on $\mathrm{BR}_{11}$ paddy field to control weeds and also to study the growth, yield components and yield. The effect of herbicides was found to be positive in controlling the weed species and in increasing the yield components and yield. The maximum number and length of tillers, length of panicle, area of flag leaves, number and percentage of filled grains, grain and straw yield per hectare were found at $\mathrm{T}_{3}$ when normal dose of Rifit $500 \mathrm{EC}$ was applied. Different doses of Machete $5 \mathrm{G}$ were also found effective in controlling weeds and increasing in yield.
\end{abstract}

Key words: Weed, Herbicides, Paddy, Aman Season

\section{Introduction}

Weeds cause problems in rice cultivation by reducing yield of rice (Smith 1970).Losses due to weeds in Aus rice, range from 58\% to complete failure of the crop (Mian and Ahasan 1969 and BRRI 1981).Weed competition was most severe ranging from 10 to 20 days after emergence of paddy. Competition of weeds is a major constraint to the productivity of wet-seeded rice because rice has no growth advantage over weeds. Grass weeds are also more difficult to hand weeding of wet seeded rice because of their similar morphology to that of rice.

The traditional methods of weed control in rice field in Bangladesh are land tillage and hand weeding which are time consuming and expensive as well. These involve a large number of man power which during the peak period is very difficult to hire (Chowdhury et al.1995). Therefore, the uses of herbicides are easier to control weeds in paddy field and comparatively involve less cost. In the present study three herbicides namely, Rifit 500 EC (Pretilachlor), Ronstar 25 EC (Oxadiazon) and Machete 5G (Butachlor) were applied in different doses in $\mathrm{BR}_{11}$ paddy grown in Aman season and their effect was studied on the control of weeds and ultimate yield components and yield of paddy.

\section{Materials and Methods}

The seeds of BR 11 paddy were sown in seed bed of $3 \mathrm{~m} \times 1 \mathrm{~m}$ in the Botanical garden, University of Chittagong. $200 \mathrm{~g}$ of seeds were evenly sown in seed bed on 17 July 2004. Watering and weeding were done in the seed bed when required. The field for transplantation was prepared in the same area by ploughing and cross ploughing and leveled properly. The field was divided into 33 plots, each measured $4 \mathrm{~m} \mathrm{x} 4 \mathrm{~m}$. 
There were eleven treatments each with three replications (block) where Complete Randomized Design (CRD) was maintained. 24 days old seedlings were transplanted from seed bed to the field on 10 August 2004. Two healthy seedlings were transplanted per hill. Row to row and hill to hill distance were maintained as $20 \mathrm{~cm}$ x $20 \mathrm{~cm}$ and there were 400 hills per plot. The fertilizers were used in the experimental fields as per following schedule: a. During last ploughing as basal dose (100 g Urea, $160 \mathrm{~g}$ TSP and 168 g MP); b. 35 day after transplantation (DAT) (110 g Urea); c. At booting stage (110 g Urea). Rifit 500 EC, Ronstar 25 EC and Machete 5G used in the present investigation as herbicide are presented in Table 1. A brief description of these herbicides is given below:

a) Rifit 500 EC: It is applied on saturated soil and pre transplanting at any time up to weed emergence. It works as cell division inhibitor. It is a selective herbicide. It is taken up readily by the hypocotyls, mesocotyls and coleoptiles. It controls annual grasses, sedges and broad leaved weeds.

b) Ronstar $25 \mathrm{EC}$ : In transplanting rice, the depth of water should be at least 3 to $5 \mathrm{~cm}$ deep and be maintained at this level for 2 to 5 days after application. It inhibits Protoporphyrinogen oxidase. It works on annual grasses and broad leaves.

c) Machete 5G: It is a protein synthesis inhibitor. It works as selective and systematic herbicide, absorbed primarily through germinating shoots and secondarily by roots; translocated throughout the plant, with higher concentration in the vegetative parts than the reproductive parts. It controls annual grasses and some broad leaves.

Table 1. Schedule of application of Rifit 500 EC, Ronstar 25 EC and Machete 5G.

\begin{tabular}{l|l|l|l}
\hline Treatment & Herbicides & Dose & Time of Application \\
\hline $\mathrm{T}_{1}$ (control) & $\begin{array}{l}\text { No herbicide was } \\
\text { used }\end{array}$ & Not applicable & Not applicable \\
$\mathrm{T}_{2}$ & $\begin{array}{l}\text { Only hand weeding } \\
\text { was done }\end{array}$ & Not Applicable & Not applicable \\
$\mathrm{T}_{3}$ & Rifit $500 \mathrm{EC}$ & $1.6 \mathrm{ml} / 800 \mathrm{ml}$ water @ $1 \mathrm{~L} / \mathrm{ha}$ & 3 days after transplantation \\
$\mathrm{T}_{4}$ & Rifit $500 \mathrm{EC}$ & Double the dose of T3 & 3 days after transplantation \\
$\mathrm{T}_{5}$ & Rifit $500 \mathrm{EC}$ & Half of the dose of T3 & 3 days after transplantation \\
$\mathrm{T}_{6}$ & Ronstar $25 \mathrm{EC}$ & $3.20 \mathrm{ml} / 800 \mathrm{ml}$ water @ $2 \mathrm{~L} / \mathrm{ha}$ & 3 days after transplantation \\
$\mathrm{T}_{7}$ & Ronstar $25 \mathrm{EC}$ & Double the dose of T6 & 3 days after transplantation \\
$\mathrm{T}_{8}$ & Ronstar $25 \mathrm{EC}$ & Half of the does of T6 & 3 days after transplantation \\
$\mathrm{T}_{9}$ & Machete $5 \mathrm{G}$ & 40gm/plot $@ 25 \mathrm{~kg} / \mathrm{ha}$ & 3 days after transplantation \\
$\mathrm{T}_{10}$ & Machete $5 \mathrm{G}$ & Double the dose of T9 & 3 days after transplantation \\
$\mathrm{T}_{11}$ & Machete $5 \mathrm{G}$ & Half of the dose of T9 & 3 days after transplantation \\
\hline
\end{tabular}

All the herbicides were applied in the BR11 paddy field three days after transplantation as per the product pamphlet. The hand weeding was done at $45\left(\mathrm{~W}_{1}\right)$ and $75\left(\mathrm{~W}_{2}\right)$ days after transplantation and during harvest (W3) in all the treatments. In control, the weeds were collected during harvest. A total of 35 weed species of 28 genera under 13 families was 
found to occur in the present experiments. Among the species, the prevalence of Fimbristylis miliacea was highest. Ludwigia adscssendens, Marsilea quadrifolia, Fimbristylis miliacea, Schoenoplectus erectus, Cyperus difformis, Cynadon dectylon and Monochoria vaginalis were obtained in all the treatments.

The paddy was harvested 117 days after transplantation, and the following data were recorded. For each treatment, five hills of the Paddy from each block were taken to evaluate the following parameters: a) Number of tillers per hill. b) Length of the tillers. c) Area of flag leaves (measured maximum length $\times$ breadth) .d) Length of panicle. e) Fresh weight of straw f) Fresh weight of grain g) Straw and grain yield h) Number of filled and unfilled grains per panicle ( Three panicles in each block ) and i) 1000-grains weight .

For chemical analysis $100 \mathrm{~g}$ of straw and grains were taken from each plot separately and then dried and grinded to powder. Powdered plant samples (straw and grains) were digested as modified Microkjeldahl method, and then NPK were determined as described by Jackson (1973). ANOVA was done to show the significant differences among the treatments following Little and Hills (1977).

\section{Results and Discussion}

Different doses of Rifit 500 EC, Ronstar $25 \mathrm{EC}$ and machete $5 \mathrm{G}$ were used in $\mathrm{BR}_{11}$ paddy field and their effects were studied on the growth, ultimate yield components and yield in Aman season. The results presented in Table 2 showed that in comparison to control all the treatments showed significant number of tiller. The number of tillers per hill increased significantly in all the treatments from $T_{1}$ due to application of herbicides and hand weeding. The highest number of tillers per hill was found at $\mathrm{T}_{3}$ (Table 2). The length of tiller decreased significantly in all the treatments from $T_{1}$ and $T_{2}$ except $T_{3}$. The highest length per tiller was found at $T_{3}$. The increase of length of tiller of the present investigation due to the application of Rifit $500 \mathrm{EC}$ was found to be consistent with the findings of Awan et. al. (2001). The area of flag leaves increased significantly in all the treatments from $T_{1}$. The highest value was at $T_{3}$ followed by $T_{8}, T_{7}, T_{10}, T_{6}, T_{5}, T_{9}, T_{4}$, $\mathrm{T}_{11}$, and $\mathrm{T}_{2}$. Except $\mathrm{T}_{2}$ the length per panicle increased significantly in all the treatments from $\mathrm{T}_{1}$.

The highest length of panicle was found at $\mathrm{T}_{3}$ followed by $\mathrm{T}_{8}, \mathrm{~T}_{5}, \mathrm{~T}_{4}, \mathrm{~T}_{7}, \mathrm{~T}_{8}, \mathrm{~T}_{6}, \mathrm{~T}_{9}$ and $\mathrm{T}_{11}$. The number of filled grains of a panicle was found to increase significantly in all the treatments from $T_{1}$. The highest number of filled grains was obtained at $T_{3}$ followed by $\mathrm{T}_{8}, \mathrm{~T}_{7}, \mathrm{~T}_{10}, \mathrm{~T}_{5}, \mathrm{~T}_{9}, \mathrm{~T}_{11}, \mathrm{~T}_{6}, \mathrm{~T}_{2}$ and $\mathrm{T}_{4}$. The number of unfilled grains per panicle was found to be significantly lower in all the treatments from $\mathrm{T}_{1}$. The lowest number of unfilled grains was found at $\mathrm{T}_{3}$ followed by $\mathrm{T}_{8}, \mathrm{~T}_{7}, \mathrm{~T}_{10}, \mathrm{~T}_{5}, \mathrm{~T}_{6}, \mathrm{~T}_{9}, \mathrm{~T}_{4}, \mathrm{~T}_{11}$ and $\mathrm{T}_{2}$. The percentage of filled grains was highest at $T_{3}$ followed by $T_{8}, T_{7}, T_{10}, T_{5}, T_{6}, T_{9}, T_{11}, T_{4}$ and $\mathrm{T}_{2}$. The number of tillers, length of panicle area of flag leaves, number of filled 
grains, and percentage of filled grains increased in almost all the treatments from $T_{1}$. The significantly increased values of the above parameters were found at $\mathrm{T}_{3}$.

Table 2. Effect of Rifit 500 EC, Ronstar 25 EC and Machete 5G on different parameters of BR 11 paddy.

\begin{tabular}{|c|c|c|c|c|c|c|c|}
\hline \multirow[t]{2}{*}{$\begin{array}{c}\text { Treatmen } \\
\text { ts }\end{array}$} & \multirow{2}{*}{$\begin{array}{l}\text { Number } \\
\text { of } \\
\text { tillers/hill }\end{array}$} & \multirow[t]{2}{*}{$\begin{array}{c}\text { Length/tiller } \\
\mathrm{cm}\end{array}$} & \multirow{2}{*}{$\begin{array}{l}\text { Length/ } \\
\text { panicle } \\
\mathrm{cm}\end{array}$} & \multirow{2}{*}{$\begin{array}{c}\text { Area of } \\
\text { flag leaves } \\
\mathrm{cm}^{2}\end{array}$} & \multicolumn{2}{|c|}{$\begin{array}{c}\text { Number of } \\
\text { grains/panicle }\end{array}$} & \multirow{2}{*}{$\begin{array}{c}\% \text { of } \\
\text { filled } \\
\text { grains* }\end{array}$} \\
\hline & & & & & $\begin{array}{l}\text { Filled } \\
(\mathrm{F})\end{array}$ & $\begin{array}{l}\text { Unfilled } \\
\text { (UF) }\end{array}$ & \\
\hline $\mathrm{T}_{1}$ & 7.73 & 95.47 & 18.83 & 25.10 & 84.69 & 16.40 & 83.78 \\
\hline $\mathrm{T}_{2}$ & 10.80 & 84.31 & 19.08 & 31.61 & 106.33 & 14.17 & 88.24 \\
\hline $\mathrm{T}_{3}$ & 12.25 & 97.15 & 23.08 & 36.79 & 131.93 & 9.09 & 93.55 \\
\hline $\mathrm{T}_{4}$ & 9.17 & 90.12 & 21.27 & 32.41 & 103.92 & 13.40 & 88.58 \\
\hline $\mathrm{T}_{5}$ & 11.00 & 95.82 & 22.10 & 32.68 & 110.10 & 12.73 & 89.64 \\
\hline $\mathrm{T}_{6}$ & 10.60 & 88.59 & 20.70 & 33.86 & 107.47 & 12.73 & 89.41 \\
\hline $\mathrm{T}_{7}$ & 10.82 & 89.93 & 21.12 & 34.79 & 113.27 & 12.00 & 90.42 \\
\hline $\mathrm{T}_{8}$ & 11.10 & 92.40 & 22.17 & 35.82 & 115.18 & 10.92 & 91.34 \\
\hline $\mathrm{T}_{9}$ & 10.33 & 86.01 & 20.32 & 32.63 & 108.94 & 13.07 & 89.29 \\
\hline $\mathrm{T}_{10}$ & 11.41 & 89.43 & 20.75 & 34.10 & 111.13 & 12.47 & 89.91 \\
\hline $\mathrm{T}_{11}$ & 10.25 & 84.39 & 19.52 & 32.29 & 108.76 & 13.66 & 88.84 \\
\hline $\operatorname{LSD}_{0.05}$ & 0.90 & 1.22 & 0.4 & 0.11 & 1.7 & 0.4 & 0.02 \\
\hline $\operatorname{LSD}_{0.01}$ & 1.27 & 1.73 & 0.57 & 0.16 & 2.42 & 0.57 & 0.03 \\
\hline
\end{tabular}

* calculated value.

The fresh weight of straw per block increased significantly in all the treatments from $T_{1}$. The highest weight of straw per block was at $\mathrm{T}_{3}$ (Table 3 ). The fresh weight of grains per plot was found to increase significantly in all the treatments from $T_{1}$ that shown in Table 3. The highest value was found at $\mathrm{T}_{3}$ followed by $\mathrm{T}_{8}, \mathrm{~T}_{7}, \mathrm{~T}_{10}, \mathrm{~T}_{6}, \mathrm{~T}_{5}, \mathrm{~T}_{9}, \mathrm{~T}_{4}, \mathrm{~T}_{11}$ and $\mathrm{T}_{12}$ (Table 3). The total fresh weight of straw and grain per plot increased significantly in all treatments from $T_{1}$. The highest value was found at $T_{3}$ followed by $T_{8}, T_{7}, T_{10}, T_{6}, T_{5}, T_{9}$, $\mathrm{T}_{11}, \mathrm{~T}_{2}$, and $\mathrm{T}_{4}$ (Table 3 ). The present findings corroborate with the findings of Budhar and Tamilseivan (2002) who had observed significantly higher grain and straw yield over hand weeding by the use of herbicides. The straw and grain ratio decreased significantly in all the treatments from $T_{1}$ and the lowest value was at $T_{4}$. Except $T_{4}$ the straw yield per hectare increased significantly in all the treatments from $\mathrm{T}_{1}$. The highest yield was obtained at $\mathrm{T}_{3}$ followed by $\mathrm{T}_{8}, \mathrm{~T}_{7}, \mathrm{~T}_{10}, \mathrm{~T}_{6}, \mathrm{~T}_{5}, \mathrm{~T}_{9}, \mathrm{~T}_{4}, \mathrm{~T}_{11}$ and $\mathrm{T}_{2}$.

The grain yield per hectare increased significantly in all the treatments from $\mathrm{T}_{1}$. The highest yield was found at $\mathrm{T}_{3}$ followed by $\mathrm{T}_{8}, \mathrm{~T}_{7}, \mathrm{~T}_{10}, \mathrm{~T}_{6}, \mathrm{~T}_{5}, \mathrm{~T}_{9}, \mathrm{~T}_{4}, \mathrm{~T}_{11}$ and $\mathrm{T}_{2}$. Matsunaka (1970) had also reported the significant increase in rice yield due to use of herbicides over hand weeding. The 1000 grain weight was found to be significant in all the treatments from $T_{1}$ except $T_{6}$ and the highest 1000-grain weight was found at $T_{3}$ followed by $\mathrm{T}_{10}, \mathrm{~T}_{9}, \mathrm{~T}_{11}, \mathrm{~T}_{5}, \mathrm{~T}_{8}, \mathrm{~T}_{7}$, and $\mathrm{T}_{4}$ (Table 3 ). 
Table 3. Effect of Rifit 500 EC, Ronstar $25 \mathrm{EC}$ and Machete $5 \mathrm{G}$ on different parameters of $\mathrm{BR}_{11}$ paddy.

\begin{tabular}{|c|c|c|c|c|c|c|c|}
\hline \multirow[b]{2}{*}{ Treatments } & \multicolumn{3}{|c|}{ Fresh weight of straw \& grains/plot } & \multirow{2}{*}{$\begin{array}{l}\text { Straw } \\
\text { and grain } \\
\text { ratio } \\
(\mathrm{S} / \mathrm{G})\end{array}$} & \multirow{2}{*}{$\begin{array}{c}\text { Straw } \\
\text { yield* } \\
\text { t/ha }\end{array}$} & \multirow{2}{*}{$\begin{array}{r}\text { Grain } \\
\text { yield* } \\
\text { t/ha }\end{array}$} & \multirow{2}{*}{$\begin{array}{c}\text { 1000- grain } \\
\text { weight } \\
\mathrm{g}\end{array}$} \\
\hline & $\begin{array}{c}\text { Straw(S) } \\
\text { kg }\end{array}$ & $\begin{array}{c}\text { Grain(G) } \\
\text { kg }\end{array}$ & $\begin{array}{l}\text { Total } \\
(\mathrm{S}+\mathrm{G})\end{array}$ & & & & \\
\hline $\mathrm{T}_{1}$ & 9.58 & 4.43 & 14.01 & 2.16 & 5.99 & 2.77 & 22.35 \\
\hline $\mathrm{T}_{2}$ & 11.52 & 7.32 & 18.84 & 1.57 & 7.20 & 4.58 & 23.16 \\
\hline $\mathrm{T}_{3}$ & 14.13 & 9.1 & 23.23 & 1.55 & 8.83 & 5.69 & 24.49 \\
\hline $\mathrm{T}_{4}$ & 10.05 & 7.63 & 17.68 & 1.32 & 6.28 & 4.77 & 23.36 \\
\hline $\mathrm{T}_{5}$ & 13.28 & 7.98 & 21.26 & 1.66 & 8.30 & 4.99 & 24.07 \\
\hline $\mathrm{T}_{6}$ & 13.38 & 8.18 & 21.56 & 1.64 & 8.36 & 5.11 & 22.40 \\
\hline $\mathrm{T}_{7}$ & 13.82 & 8.45 & 22.27 & 1.64 & 8.64 & 5.28 & 23.40 \\
\hline $\mathrm{T}_{8}$ & 14.00 & 8.93 & 22.93 & 1.57 & 8.75 & 5.58 & 23.79 \\
\hline $\mathrm{T}_{9}$ & 13.10 & 7.75 & 20.85 & 1.69 & 8.19 & 4.84 & 24.26 \\
\hline $\mathrm{T}_{10}$ & 13.72 & 8.38 & 22.10 & 1.64 & 8.58 & 5.24 & 24.29 \\
\hline $\mathrm{T}_{11}$ & 11.85 & 7.35 & 19.20 & 1.61 & 7.41 & 4.60 & 24.10 \\
\hline $\operatorname{LSD}_{0.05}$ & 0.63 & 0.13 & 0.02 & 0.02 & 0.42 & 0.08 & 0.41 \\
\hline $\operatorname{LSD}_{0.01}$ & 0.89 & 0.18 & 0.03 & 0.03 & 0.59 & 0.11 & 0.58 \\
\hline
\end{tabular}

* calculated value.

The $\mathrm{N}$ concentration of straw increased significantly in all the treatments from $T_{1}$. The highest value was obtained at $\mathrm{T}_{8}$ followed by others (Table 4 ). The $\mathrm{P}$ concentration of straw showed significantly in all the treatments from $T_{1}$. The highest value was at $T_{4}$ followed by others. The highest value of $\mathrm{K}$ in straw was at $\mathrm{T}_{8}$ followed by others . The total NPK concentrations of straw increased significantly in all the treatments from $T_{1}$. The highest value was at $\mathrm{T}_{8}$ followed by others. In $\mathrm{N}: \mathrm{P}: \mathrm{K}$ of straw, $\mathrm{N}$ concentration was found to be maximum at $T_{3}$. The $P$ concentration of $N: P: K$ was maximum at $T_{10}$. The $K$ concentration of $\mathrm{N}: \mathrm{P}: \mathrm{K}$ was found maximum at $\mathrm{T}_{2}$. The $\mathrm{N}$ concentration of grains increased significantly in all the treatments from $T_{1}$. The highest value was at $T_{11}$ followed by $\mathrm{T}_{9}, \mathrm{~T}_{8}, \mathrm{~T}_{4}, \mathrm{~T}_{5}, \mathrm{~T}_{3}, \mathrm{~T}_{6}, \mathrm{~T}_{7}, \mathrm{~T}_{10}$ and $\mathrm{T}_{2}$. The $\mathrm{P}$ concentration of grains was found significantly in all the treatments from $T_{1}$. The highest value was at $T_{6}$ followed by $T_{11}$, $\mathrm{T}_{10}, \mathrm{~T}_{4}, \mathrm{~T}_{5}, \mathrm{~T}_{9}, \mathrm{~T}_{8}, \mathrm{~T}_{2}, \mathrm{~T}_{3}$, and $\mathrm{T}_{7}$. Except $\mathrm{T}_{7}$ the $\mathrm{K}$ concentration of grains was found to be increased significantly in all the treatments from $T_{1}$. The total NPK concentration of grains significantly increased in all the treatments from $T_{1}$. The highest value was at $T_{11}$. In $\mathrm{N}: \mathrm{P}: \mathrm{K}$ of straw, $\mathrm{N}$ concentration was found to be maximum at $\mathrm{T}_{9}$. The $\mathrm{P}$ concentration of $\mathrm{N}: \mathrm{P}: \mathrm{K}$ was maximum at $\mathrm{T}_{1}$. The $\mathrm{K}$ concentration of $\mathrm{N}: \mathrm{P}: \mathrm{K}$ was found to be maximum at $\mathrm{T}_{2}$ (Table 4).

The individual increase of $\mathrm{N}, \mathrm{P}$ and $\mathrm{K}$ was found in all the treatments from the unwedded control $\left(\mathrm{T}_{1}\right)$ but no definite trend of increase was observed. However, the total NPK concentration was observed maximum at $\mathrm{T}_{8}$ when half of the dose of Ronstar was applied. The total NPK concentration of grain was found maximum at $T_{11}$ when Machete half dose was applied. 
Table 4. Effect of Rifit 500 EC, Ronstar $25 \mathrm{EC}$ and Machete $5 \mathrm{G}$ on $\mathrm{N}, \mathrm{P}$ and $\mathrm{K}$ concentrations** on straw and grains of BR 11 .

\begin{tabular}{l|c|c|c|c|c|c|c|c|c|c}
\hline \multirow{2}{*}{$\begin{array}{c}\text { Treatm } \\
\text { ent }\end{array}$} & \multicolumn{9}{|c|}{ Straw } & \multicolumn{4}{c}{ Grain } \\
\cline { 2 - 11 } & $\mathrm{N}$ & $\mathrm{P}$ & $\mathrm{K}$ & $\begin{array}{c}\text { Total } \\
\text { NPK }\end{array}$ & $\mathrm{N}: \mathrm{P}: \mathrm{K}^{*}$ & $\mathrm{~N}$ & $\mathrm{P}$ & $\mathrm{K}$ & $\begin{array}{c}\text { Total } \\
\text { NPK }\end{array}$ & $\mathrm{N}: \mathrm{P}: \mathrm{K}^{*}$ \\
\hline $\mathrm{T}_{1}$ & 0.47 & 0.20 & 0.66 & 1.33 & $35.34: 15.04: 49.62$ & 0.42 & 0.54 & 0.43 & 1.39 & $30.21: 38.85: 30.93$ \\
$\mathrm{~T}_{2}$ & 0.63 & 0.30 & 0.95 & 1.88 & $33.51: 15.96: 50.53$ & 0.91 & 0.68 & 0.73 & 2.32 & $39.22: 37.07: 31.46$ \\
$\mathrm{~T}_{3}$ & 0.84 & 0.32 & 0.87 & 2.03 & $41.37: 15.76: 42.86$ & 1.12 & 0.65 & 0.57 & 2.34 & $47.86: 27.78: 24.36$ \\
$\mathrm{~T}_{4}$ & 0.70 & 0.58 & 0.72 & 2.00 & $35.00: 29.00: 36.00$ & 1.19 & 0.76 & 0.63 & 2.58 & $46.12: 29.46: 24.42$ \\
$\mathrm{~T}_{5}$ & 0.70 & 0.54 & 0.94 & 2.18 & $32.11: 24.77: 43.12$ & 1.19 & 0.76 & 0.65 & 2.60 & $45.77: 29.23: 25.00$ \\
$\mathrm{~T}_{6}$ & 0.70 & 0.43 & 0.81 & 1.94 & $36.08: 22.16: 41.75$ & 1.12 & 0.82 & 0.72 & 2.66 & $42.10: 30.83: 27.07$ \\
$\mathrm{~T}_{7}$ & 0.84 & 0.55 & 0.95 & 2.34 & $35.89: 23.50: 40.59$ & 1.12 & 0.64 & 0.49 & 2.25 & $49.78: 28.44: 21.78$ \\
$\mathrm{~T}_{8}$ & 1.00 & 0.52 & 1.03 & 2.55 & $39.21: 20.39: 40.39$ & 1.26 & 0.69 & 0.65 & 2.60 & $48.46: 26.54: 25.00$ \\
$\mathrm{~T}_{9}$ & 0.85 & 0.54 & 0.95 & 2.34 & $36.32: 23.08: 40.59$ & 1.38 & 0.73 & 0.54 & 2.65 & $52.07: 27.55: 20.38$ \\
$\mathrm{~T}_{10}$ & 0.64 & 0.57 & 0.72 & 1.93 & $33.16: 29.53: 37.30$ & 1.1 & 0.79 & 0.54 & 2.43 & $45.27: 32.51: 22.22$ \\
$\mathrm{~T}_{11}$ & 0.7 & 0.57 & 0.91 & 2.18 & $32.11: 26.15: 42.74$ & 1.4 & 0.80 & 0.50 & 2.70 & $51.85: 29.63: 18.52$ \\
$\mathrm{LSD}_{0.05}$ & 0.01 & 0.03 & 0.05 & 0.06 & & 0.05 & 0.04 & 0.04 & 0.07 & \\
$\mathrm{LSD}_{0.01}$ & 0.02 & 0.04 & 0.07 & 0.08 & & 0.07 & 0.06 & 0.06 & 0.10 & \\
\hline
\end{tabular}

* Calculated value, ${ }^{* *} \mathrm{~g} \%$ of dry weight basis

In the present experiment, $\mathrm{T}_{3}$ was found to be most effective in increasing the yield components and yield of BR11 paddy. At $\mathrm{T}_{4}$, double the dose of Rifit $500 \mathrm{EC}$ was used where the yield did not increase accordingly. This may have toxic effect of the double the dose of Rifit. So, normal dose of Rifit 500 EC (1.6ml/800ml water @ 1L/ha) may be recommended.

\section{References}

Awan, I.U., T. Abbass and M.A. Nadeem. 2001. Production Efficacy of Six rice Cultivars Against Various Herbicides Applied for Weed Control Indirect Wet -Seeded Rice (Oryza sativa L.) Culture. On LineJjournal of Biological Sci. 1(9): 828-830.

BRRI. 1981. Annual report of Bangladesh Rice Res. Inst. for 1978-79. PP. 21-22.

Budhar, M.N. and. N. Tamilseivan. 2002. International Rice Research Institute. Notes: P.28.

Chowdhury, M.A.H., N.M. Talukder, A.K. Chowdhury and M.Z. Hossan. 1995. Effect of Ronstar on weed management, yield and nutrient uptake by rice. Bangladesh J. Agril. Sci. 22(1):93-97.

Jackson, M.L.1973. Soil Chemical Analysis. Prantice-Hall of India. Pvt.Ltd. New Delhi. PP.27-28

Little, T.M. and F.J.Hills. 1977. Agricultural Experimentation. John Wiley and Sons. Ltd. USA. PP.21-25.

Matsunaka, S. 1970. Weed control in rice. Technical papers of the FAO Int. Conf. on Weed Control, Davis, California, USA. PP.7-23.

Mian, A.L. and M.A. Ahasan. 1969. A comparative study on the performance of IR8 and Dharial Varieties of rice grown by different methods of planting under different combinations of nitrogen, phosphorus and potassium, Pakistan J. Sci. 21 (1-2):30-35.

Smith, R.J.Jr. 1970. Weed control Methods, losses and costs due to weeds and benefits of weed control in rice. FAO Internal. Conf. on Weed Control. Davis, Calif. P.24-27 (Cited in Craft).

(Received revised manuscript on 24 April 2013) 